\title{
GRASPING FOR GOD IN THE MATERIAL: A MEDITATION ON LUTHER'S THEOLOGY OF CREATION AND ACCOUNT OF SIN AS CRITICAL RESPONSE TO THE ECOLOGICAL CRISIS
}

Wyatt Harris

Emory University

Abstract

This essay explores the potential contribution of Martin Luther to the current thinking around the ecological crisis. In particular, I argue that Luther's understanding of sin should be brought into consideration in order to understand why humanity struggles to change its various courses of action vis-a-vis the ecological crisis. The essay examines numerous ecologically conscious critics of the Western theological tradition and identifies merits and shortcomings in their thinking, and I bring Luther forward to address such shortcomings. I finally turn to elements of Luther's creation theology in order to open up potential paths forward for thinking through the ecological crisis.

Keywords: Luther; Sin; Creation; Ecologically conscious; Material

In a recent article on climate change, How extreme weather is shrinking the planet (The New Yorker Nov 26, 2018), Bill McKibben presents harrowing statistics detailing the extreme weather that continues to ravage our planet. This weather harms the land, kills off numerous animal and plant species, and causes continual anxiety, suffering, and displacement of humans all around the globe. And, as is well known by now, the overwhelming evidence is that human activity is a fundamental cause of global warming and the current ecological crisis. McKibben narrates the ways in which our world's largest companies, for example Exxon, employ strategies to manipulate the public into thinking that scientific data remains unclear about the damage being done to the planet by human activity. Such companies are well aware of the scientific data and analyses concerning climate change. Why do they not act? Or, put differently, why do they not curb their activity? McKibben admits there are numerous "intellectual, psychological, and political sources for our inaction", but he identifies one reason in particular: humanity's "virtue of selfishness". No doubt fueled in ways beyond our imagination by "unbridled capitalism", habituated human selfishness remains the largest obstacle to change. Of course, human failure and evil have always been problematic and are responsible for numerous catastrophes - natural or otherwise - throughout our history on this earth. What global warming, climate change, and the continuous destruction of our planet (with no end in sight!) critically bring to the forefront of our attention, however, is a reckoning for the human species. It has finally become apparent that not only are we capable of ruining the future of our existence (and conterminously that of every other living thing on earth in the process), but that we actually are doing so, slowly but surely. 
I draw attention to this piece from The New Yorker not only because it highlights the most recent details of the situation for a general audience, but more importantly because McKibben zeroes in on an acute issue that plagues humanity and stunts enforces our activity: our selfishness. We will not act for positive change because we are selfish, willfully so! Not only are we selfish, but we have habitually sedimented this selfishness over the course of our entire existence as a species. Many of us are so wrapped up in ourselves that we willingly (or unwillingly!) remain in ignorance of the situation. To make matters worse, if we finally are fortunate enough to have an epiphany and realise the critical nature of the climate crisis, we often move towards despair. For one thing, nature is often beyond our scale of comprehension. ${ }^{1}$ For another, structural resistance from governments, companies, and the upper-class, present apparently insurmountable obstacles. The latter groups continue to pursue economic growth and technological development at the expense of those who have no access to it, as well as in willful ignorance of the destruction such pursuits wreak on those who will not benefit. No wonder we despair.

How do we go about undoing our habits and start changing ourselves and our actions, so that we might begin to effect the necessary changes to fight climate change? Most of what we do in this regard, whether as individuals or collectively, remains deeply challenging work and often seems small in the grand scheme of things. Our individual and collective efforts are miniscule relative to the massive scale of structural, global capitalism, or more neutrally, to the radical technological interconnectivity in which we are located. It seems like we cannot ever keep up. Moreover, someone or some group always has a take, a protest, a solution, or a critique. In light of this situation, this essay's attempt at an analysis of humanity's plight is no different, but an attempt must be made. McKibben calls for "solidarity and coordination on a global scale". He believes "the possibility of swift change lies in people coming together in movements large enough to shift the Zeitgeist". These suggestions are surely correct. The problem is, how does this process even begin? Where do we start? Before we answer that, however, we need to dig a bit deeper and examine an issue lying behind our activity and inactivity. We need an account of the origin of both our selfishness and despair before we begin to change the Zeitgeist, or, in more familiar language, our collective self-consciousness.

The story that human beings are selfish and ignorant, and have caused much damage as a result of habituating such vices, and thus turn to despair when change seems impossible, is one which was told in a theological vein by Martin Luther more than 500 years ago. Luther, of course, was not the first theologian to ruminate on this problem, though, as I hope to demonstrate, his analysis is unique. For Luther, our sin is nothing other than our selfishness. Human beings are sinful, through and through. In fact, our status as sinners goes back to the very origin of our species. ${ }^{2}$ In what follows, I examine Luther's account of sin and the law-like grip it holds over our lives, in order to offer a theological response to the great ecological crisis of our time. I will argue that in his account of sin Luther identifies the precise issue of why we are unable to effect change, and that his diagnosis of the situation at the theological level presents a possible path

Kant's analysis of the sublime in Critique of the power of judgment notwithstanding.

Whether a literal origin such as religious-historical accounts like that found in the book of Genesis, or an emerging coming-to-be of our species through the process of evolution, matters little for the point Luther argues. 
forward for the necessary change in our collective self-consciousness which is adequate to address an issue as large as climate change. The argument that Luther's proposal on the theological level is worthy of consideration stems in part from my own growing dissatisfaction with the increasingly repetitious ways ecologically informed theological discourse addresses the crisis. As will hopefully become apparent in my analysis, Luther's intervention is crucial, because the necessary, deep changes of our collective self-consciousness for addressing the crisis are in fact not being made, but the same criticisms and solutions are repeated again and again. The criticisms - critiques of anthropocentrism and dualism in theology, to name two of the most important, which will be unpacked in more detail below - and proposed solutions are not in themselves wrong. Luther, in fact, would agree with many of them! However, such ecologically informed thought often misses the problem at the deepest theological level: humans are sinners through and through and thus cannot make the changes necessary without the agency and Word from a graceful God. As a result, far from stifling human action from the start - a critique all-too-often directed at him ${ }^{3}$ - Luther's account of sin and grace provides the separation humans need from their own selves, individually and collectively, in order to be freed and reoriented, thus allowing them to then take new steps to shift the Zeitgeist.

This argument will proceed in three steps. Because Christian theology in its classic Western expression has been largely blamed for creating the conceptual space and habits out of which the ecological crisis has emerged, a theological response from a classical Western theologian (Luther) might appear an odd place to turn. First, then, I examine the charges the ecologically conscious perspective levels at Christianity. This will make evident the novelty of Luther's intervention, for we will see that, though he too made similar accusations against the tradition, the standard critique from the ecologically informed religious perspective hits the wrong target at the deepest theological level. Deepening the analysis of the latter, I next present Luther's account of sin. This is the heart of the paper and involves some extended exposition of Luther's texts. Finally, I briefly turn to Luther's theology of creation to offer a few hints of how we could utilise it as a constructive resource for shifting the Zeitgeist. Luther's account will appear just as provocative today as it did in his own context. Now, however, as we grow desperate, perhaps the great reformer deserves a second look. Recognising with McKibben that the reasons for, and solutions to, our crisis are many, I must state at the outset that I limit my analysis to one such reason, the role of theology.

\section{Criticism at the source of the crisis 1: Problems in Western Christianity}

Regarding the ecological crisis, one way in which religious reflection and theology often respond, is to identify the problems, and then bring the issues before our consciousness so as to effect their change. In order to do this, theology creates new concepts and explores new territory. The latter involves wisely engaging in dialogue with other disciplines, most importantly the sciences of biology, physics, and other related fields and subfields. Science certainly moves religion to reconsider many of its inherited 
assumptions. ${ }^{4}$ Theology also looks backward into its history for other voices and texts that might provide help; ${ }^{5}$ in the process, standard texts and thinkers too are mined for any conceptual aid they might offer the present.

In his pioneering 1967 article, The historical roots of our ecologic crisis, Lynn White Jr. (White 1967:1203-1207) turns to the life and thought of St. Francis to aid the reshaping of our consciousness. White's article was the bombshell that startled the West into examining the causes that led to the ecological crisis. In it he argues that scientific and technological advances in the West, fueling humanity's desire to dominate nature, grew naturally out of a matrix of thought thoroughly revolving around the human being. This matrix is none other than the doctrinal and moral teaching of Christianity, centred as it is on Jesus Christ, the God-man. This focus on Jesus only affirms what White sees as the major problem: the Judeo-Christian teaching that humanity is the apex of creation. Made in the image of God, human beings mirror God's own transcendence over nature, thus opening the way for domination and mastery over it. White's accusation that Christianity's extreme anthropocentricism ${ }^{6}$ is primarily responsible for the crisis, precipitated a scramble to rethink Christianity's legacy in relation to creation, the earth, and science. As noted above, if a reversal of the trends is even possible, White must seek other conceptual frameworks. He turns to St. Francis, who embodied humility toward nature and levelled the creaturely playing field: human beings are not special, but equal with all other living beings. We can grasp the radicality of Francis' thought, but we must abandon dualistic notions of the God-creature relation and adopt another model: immanence and a "pan-psychism of all things animate and inanimate" (White 1967: 1207). White claims that Francis ultimately had to fail because Christian orthodox thinking has (and already had!) so permeated the Western mind that resources for change cannot be sought there.

Though evolutionary biology presented an alternative paradigm for reconsidering the God-creation relation well before White's trenchant critique, it was White who provocatively opened the door for a significant renewal of theological attention to creation. His precise reading of the extent to which various church doctrines led to irresponsibility toward, or more drastically, damage of, creation is debatable, but the hints for change he set forth in 1967 remain the core of theological reflection on the ecological crisis. A few more voices will be sampled at random here. Building on themes latent in White's work, Rosemary Ruether, a Catholic and feminist theologian, traces the problem further by drawing attention to the parallel between the subjugation of women and that of nature. Because the female is historically associated with materiality, man as the rational animal is seen as superior. When this is the case, a "male-defined point of view" predominates, and the trajectory of Western politico-scientific-religious thought develops in this vein, leading in the end to "the nightmare" of the ecological crisis (Ruether 1993:20). In this sense, following Reuther, women may not be subject to the

Of course, one can cite Copernicus' and Darwin's breakthroughs in cosmology and biology (evolution) respectively as two major examples of this.

5 For a recent, powerful retrieval of Luther himself on this score, though for slightly different reasons than my own utilisation of him, see Cynthia D. Moe-Lobeda (2002:73-99).

6 According to White: "Especially in its Western form, Christianity is the most anthropocentric religion the world has seen" (1967:1205). As a result, Christian practice "not only established a dualism of man and nature but also insisted that it is God's will that man exploit nature for his proper ends" (ibid.). 
same sin of selfishness. ${ }^{7}$ Like White, Ruether seeks ways of changing consciousness: human consciousness is that which emerges out of nature - it is "the place where nature itself becomes conscious" (Ruether 1993:21). All species, according to Ruether, are interconnected and on the same plane, and God is simply the immanent source and energy of all life in its continual emergence and process. No dualism here! To reflect natural processes we must act justly in a deeply interconnected material reality. The earth, not some out of this world transcendence, needs to become the focus of our consciousness.

Irish systematic theologian Anne Primavesi, in her expansive work on Gaia science, ${ }^{8}$ argues that humanity's differentiation from all other living species is very hard to grasp. Evolution and Gaia science have essentially proven that human beings are organisms which evolve with their environment just as all other species do. ${ }^{9}$ Thus, in tandem with insights from White and Ruether, Primavesi's maxim for human activity is as follows: do our concepts and practices, "through a positive conjunction of sacred, technological and political power, sustain reverence for, and so safeguard the living systems which form our communities? Or negatively, do they continue to sanction violence against any of them?" (Primavesi 2000:15). For Primavesi, theology is the science of the earth, and all knowledge of God thus emerges from our co-evolution with the living organism (Gaia) that is the planet (2000:20). Thus, how we treat the earth, since we evolve with it, determines the justice that future evolutions will inherit; we act justly vis-à-vis God and creation when no violence is done to either. Whites' and Ruether's concerns are expressed in this non-anthropocentric logic. We must improve the world by our own efforts, as our actions directly impact all other living species in our co-evolving environments, including God. The world is one fragile but dynamic becoming with an open future. To connect this back to McKibben's call to action: what we do with, and how we treat, our environment determines the future of our planet, species, and, yes, our relationship with God. God is immanent, so we will either live in fear of the unknown, of the fragile and dangerous dynamic becoming that is God, or vis-à-vis the latter, we will proceed justly, by developing habits of non-violence.

Finally, theologian Gordon Kaufman goes so far as to challenge theological thinking in an awakened age to rid itself of all concepts of a personal God altogether. For Kaufman, the thought-systems of Judeo-Christian-Islamic theology inevitably allied themselves with the personal God Yahweh, who won the battle over-against the Canaanite deities which were fully intertwined with natural processes and seasonal cycles of the earth. Like White, Kaufman sees in Western monotheism the disassociation of humanity from nature, due to God's demand that reverence for anything other than the divine moral law promotes idolatry. Because of this - as science and technology advance in the West, both of which are fully dependent on the natural order and our understanding of it - our worship of God as personal lawgiver and conversation-partner only widens the gap between humans and nature. This is because our god-concepts are

7 For more on this, and for a critique of the claim that $\sin$ is fundamentally "pride" (selfishness), see the helpful analysis of Serene Jones (2000:49-68, 94-125).

8 Seen most fully in Anne Primavesi (2000).

9 "The first surprise then, of a Gaian perspective, is that on the basis of our physical components, we cannot ... draw a convincing line between plants and animals, or between our lineages and those of other living organisms" (Primavesi 2000:16). 
human concepts, and as a result we anthropomorphise deity. Kaufmann thus calls on humans to abandon anthropomorphic god-concepts in order to overcome our anthropocentrism and to imagine afresh god-concepts learned from our experience of nature and ecology. Scientific truths, such as that of evolution, demand this. We must respond to this challenge "in appropriately creative ways" and "devote ourselves to bringing about the more humane and ecologically rightly ordered world to which we all aspire" (Kaufman (2000:22-27). Hence Kaufman's own depiction of God as "Creativity" in his final works. ${ }^{10}$

We can sum up this section by identifying these various authors' common concerns and proposals for altering the resultant inherited consciousness. Orthodox Christianity bequeathed to the Western world a framework with humanity at its centre. Because humanity is understood to be in the image of God, the transcendent creator, the moral lawgiver and all-powerful judge, humans mirror such transcendence, and dominate the natural world as a response. Humanity's concern in this paradigm is to worship and do the will of God. Since God is transcendent, the focus of our attention is on pleasing a God who is not necessarily found in nature. An immediate consequence results when man is understood to be the image, so all creatures other than the male species are inherently inferior. In such a hierarchy's different iterations of dualistic thought (male//female, spirit//matter, etc.), care for the earth and supposedly "inferior" species falls by the wayside. We pursue our own agendas to the neglect of all else. This plays out in our concern for salvation from the material and our apparent right, as masters over nature, to accumulate economic wealth or political power. Thus, we need ways of deconstructing such deeply rooted thought patterns and new resources for moving forward. If we do not, we will continue to harm both the earth and its living species, including ourselves. The thinkers alluded to above propose new concepts and turn to other discourses (primarily the sciences) in order to bring about the necessary change. ${ }^{11}$

There is much to learn from the continually expanding discourse on ecology and theology. For our purposes here, however, this discourse's crucial (and correct) insight is its location of the root of our problems in Christianity's anthropocentrism. Problematic notions of transcendence, projected dualisms and hierarchies, and unjust aspirations of progress centred on the human species as fulfillment of all reality, all result from such a distorted conceptual matrix. As a species we simply cannot continue within that framework. The consequences have been duly noted. And to return to this paper's original claim, this anthropocentric framework is found at the root of our selfishness. Or, perhaps more incisively put: our selfishness is the root of our anthropocentric framework. Luther would certainly agree: the extreme selfishness of the human species,

See especially Gordon D. Kaufman 2004 and 2006.

1 Of course, I realise that there are myriad other voices worth paying attention to, but space limits the sampling. The critiques and themes such voices all share, are indeed captured in my small sampling. I would, however, like to note two significant discourses not included in my sampling: the biblical scholars and the poets, mystics, and contemplatives. Many biblical scholars have returned to the biblical text to examine them from an ecological perspective. This is done in many ways: attention is given to the general theme of creation; individual biblical figures and authors are examined for their particular ecological voices; and perhaps most interestingly, the perspective of the earth itself is speculated on. Alternatively, the poets, mystics, and contemplatives offer rich resources for a completely different style of envisioning humanity's relation to nature, God, and all other living beings. Extended contemplation of nature, or meditational practice, among other things, yield alternative ways for imagining the world and our place within it. 
a consequence of anthropocentrism, ${ }^{12}$ is the major problem. This anthropocentrism is sinful. All the horrifying consequences that result, are sins, and must be judged accordingly. The great sin of the Western world is that we have made it all about us. ${ }^{13}$ For Luther, however, this diagnosis is only half-correct. In fact, the missing half is far more serious. The problem, Luther thinks, is not with Christianity per se; rather, the problem is with a particular iteration of Christianity, distorted by our sinful nature, seen most clearly, for example, in the influence of Aristotle over Western theology's standard account of theological morality. To see why this is so, we now turn to Luther's account of $\sin$.

\section{Criticism at the source of the crisis 2: Luther Luther on the sinful state of humanity}

From the beginning to the end of his theological career, Luther maintained the notion that the actions of human beings, without the justifying grace of God that comes $a b$ extra nos, are thoroughly sinful. I will look at two early texts of Luther's to elucidate this idea. In his 1517 Disputation against scholastic theology (Luther 1957), Luther proffers his position (which would henceforth remain basically unaltered) on sin, theological anthropology, and the God-creature relation. In thesis four, he states that "man, ${ }^{14}$ being a bad tree, can only will and do evil (Cf. Matt. 7:17-18)" (Luther 1957:9). As a consequence, humanity does not have a free will to choose between different routes of action, and, more seriously, our wills are in fact totally corrupt: "without the grace of God the will produces an act that is perverse and evil" (Luther 1957, theses 5 and 7). Because of sin, the human will is "inevitably evil and corrupt" (Luther 1957:10, thesis 9). These fundamental theses open up wider problems. The problem with a corrupt and evil will, is that "Man is by nature unable to want God to be God. Indeed, he himself wants to be God, and does not want God to be God. To love God above all things by nature is a fictitious term, a chimera, as it were. This is contrary to common teaching" (Luther 1957:10, thesis 9). It is not that we are incapable of doing any good works whatsoever; the point is rather that, being sinful by nature, the works we actively do, are disoriented from the outset. Our prospects look rather dim at this point, but Luther continues, telling us that hope for humanity "does not grow out of merits, but out of suffering which destroys merits" (Luther 1957, thesis 25). If humans are indeed to undertake any action that is good or just, they will only be able to do so by the grace of God which kills and re-creates the will. ${ }^{15}$ For this process to happen, "nothing precedes

12 Luther does not speak of "anthropocentrism" per se; however, as we will see below in various works, Luther offers similar arguments against what we understand today as anthropocentrism.

13 This charge transcends the topic of this paper and equally should be made regarding the West's colonialism and imperialism, among other things. Of course, the ecological crisis, capitalism, imperialism, colonialism, and so on, are intricately related.

14 When quoting Luther directly, I will adopt his use of the German "mensch" as rendered in English as "man" in the American edition of his works, as representational of humanity.

15 Luther often situates the death of the will, i.e., the human subject, in conjunction with death and resurrection in baptism: "Baptism, then, signifies two things - death and resurrection, that is, full and complete justification ... This should not be understood only allegorically as the death of sin and the life of grace, as many understand it, but as actual death and resurrection. For baptism is not a false sign" in Luther's works 36 : Word and sacrament II (1959: 67-68). For more on the reality of the death and resurrection of the sinner beyond mere allegory, and also beyond mere transformation of the will, see Gerhard O. Forde (1990:1-19). 
grace except indisposition and even rebellion against grace" (Luther LW 31:11, thesis 30). Thus, human nature is totally corrupt due to sin. Whatever they do, outside of grace, humans can do nothing good. A bad tree only produces bad fruit, and as bad trees, humans cannot do anything that might prepare for grace, or that might merit God's favour. Without reference to the vertical dimension of our existence before God, human moral capacity for goodness on the horizontal plane always remains relatively good, or just, depending on the historical, cultural, and social context and the latter's prevailing standards of goodness and justice. These contexts are, however, often in conflict with each other.

This is a dreadful picture of the state of the human being. Against all common sense, Luther then lays down two of his most well-known theses concerning the human will and ethical behavior. Thesis 40: "We do not become righteous by doing righteous deeds but, having been made righteous, we do righteous deeds. This is in opposition to the philosophers." (Luther LW 31:12). Thesis 41: "Virtually the entire Ethics of Aristotle is the worst enemy of grace. This is in opposition to the scholastics." (Luther LW 31:12). The target here is Aristotle's opposite position: "so too we become just by doing just acts, temperate by doing temperate acts, courageous by doing courageous acts" (Aristotle 2014:238). What Luther opposes, is the human tendency to make something of oneself, or, as Aristotle says, "performing” (Aristotle 2014:238). Common sense, however, tells us that the habitual performance of kind deeds over time solidifies an inherent kindness in the person who performs the kind deeds. This is the development of virtue. ${ }^{16}$ The same habit-forming process occurs with evil deeds. But due to our corrupt nature, habitual actions do not allow us to make anything of ourselves, especially not positively in the direction of the good. How then, do we ever perform a good deed, or identify an action as good? By grace. However, since our will is evil, grace must free us from our own selfjustification and self-analysis. Grace is that divine favour of God that constitutes our being relative to God as good, and thus, under such favour, our works become good. It is not that God now does our works for us; rather our works are declared "just" or "good" by God as God now sees us in the image of Jesus Christ. ${ }^{17}$ Indeed, "The grace of God is never present in such a way that it is inactive, but it is a living, active, and operative spirit." (Luther $L W$ 31:13, thesis 55). Luther claims that the human will neither is oriented toward the good, nor that such a faculty exists neutrally in human subjects prior to willing and choosing courses of action. Such a faculty would be static, inactive, yet should somehow be able to move a person to act. ${ }^{18}$ Luther denies the existence of such a faculty. There is no priori faculty in humanity that corresponds to something like "the good", let alone God. Thus, when we act, we do not imitate God, nor act as God's image. In this sense, we could say, regarding critiques of hierarchy and transcendence in section 1 above, that here we see implicit in Luther's thought a similar criticism of human self-

16 This is beside the point here, but it is nonetheless worth pointing out that virtue ethics is inherently circular. Do we not need virtues inherently in order to perform virtuous acts to begin with? Yet development of a virtuous being requires the habitual, repetitive practice of forming a virtuous self.

17 For a systematic treatment of the difference between grace and work, where the two concepts are thoroughly distinguished, i.e., where grace is not a power that does work but instead is that concept that tells us how God now sees us favourably in Christ, see Eberhard Jüngel (2014:168-198).

18 Such as that supposedly inherent virtue in the human subject that is a priori oriented toward the good, i.e., the virtuous habit. 
transcendence hypothetically oriented to, or participating in, God's own transcendent essence. When we propose it in our own image, inevitably it reflects our distorted will.

Luther goes on to say that without grace, humanity is incapable of fulfilling God's law. Whether this is God's revealed law (the Torah, for example), or the existential law of the conscience, Luther argues that "a good law will of necessity be bad for the natural will" (Luther $L W 31: 14$, thesis 70). In fact, the law and the will are incompatible. Again upbraiding common sense, Luther states that, "The law makes sin abound because it irritates and repels the will" (Luther $L W 31: 14$, thesis 74). The law does not presuppose that humans can live up to it. Instead, the law's job is to reveal sin. Luther suggests that without the grace of God, our obedience to the law only signifies that we obey it for our own advantage, whatever that may be (Luther $L W 31: 14$, thesis 78). If the law only reveals sin, it condemns us; thus, "condemned are all those who do the works of the law" (Luther $L W 31: 14$, thesis 79). Since this is the case, Luther dramatically asserts that humans hate the law. How could they not hate something that consistently condemns? Of course, we would prefer to have a free will and so choose how to act. But this is exactly what we do not have. For this reason, again, Luther states that only the grace of God in Jesus Christ "makes justice abound" (Luther $L W 31: 14$, thesis 75), and that "grace as a mediator is necessary" in order for us to be right with God and love God and the neighbour accordingly. God's grace is necessary because God alone is not bound by the law. Loving God and loving the neighbour, are acts contrary to our disposition and nature; thus, to actually love God, we must "hate oneself and ... know nothing but God" (Luther $L W 31: 15$, thesis 95).

Luther adds to the above picture in his Heidelberg disputation (1518), where he states with more clarity: "Free will, after the fall, exists in name only, and as long as it does what it is able to do, it commits a mortal sin. Free will, after the fall, has the power to do good only in a passive capacity, but it can always do evil in an active capacity" (Luther $L W 31: 40)$. Luther clarifies that the human doing of good works happens only as a result of a prior passivity. This means that God mercifully declares the goodness and justness of humans which then frees them to do a good and just work. God relieves our entrapment in our own self-consciousness. Without God, we have no way of knowing whether our works are good or just. Relative to God, humans are purely passive creatures. From our side we do not relate positively to God in any way. Our existence is not by nature oriented toward God or some abstract principle of "the good". Commenting on this latter idea, Luther parallels contemporary criticisms of transcendence: "That person does not deserve to be called a theologian who looks upon the invisible things of God as though they were clearly perceptible in those things which have actually happened (Rom. 1:20)" (Luther LW 31:40). What Luther is criticising here, are anthropocentric (not anthropomorphic!) notions of the God-creature relation. Because our wills are so corrupt, our God-concepts are too. We cannot help but project God's being falsely, in our own image, or according to what or whom we wish God to be. But this simply posits a false notion of transcendence, as noted above. Prior to the reception of grace, we only project false notions of God (transcendence), of whatever notions these end up being: God as male, God as female, God as tyrant, God as the abstract "Good", God as process, God as the world, God as humanity, etc. 
How did we get to be in such a wretched position? For the ecologically conscious theologian, the problem is humanity as Christianity has commonly articulated it. Humancentredness leads to all the problems of our disastrous relationship to the world, ourselves, and God. For Luther, however, the problem is also humanity, but humanity under sin, though the consequences are much the same: disastrous and distorted relations. Humanity in the state of sin cannot help but act selfishly. As Luther recognises, obedience to the law without grace is simply a selfish act: we only obey the law out of concern for ourselves. If we doubt this, Luther tells us to reflect on the matter, and we quickly discover he is right. At the very least, we never live up to the standards of our own conscience. At best, even if we have God's law, how do we know if we have obeyed it with all our being (Deut. 6:4)? We are stuck with ourselves, obsessed with ourselves, our power, and our abilities, and we are close neither to God nor to good activity. ${ }^{19} \mathrm{In}$ order to see why this is the case, we need to look at Luther's account of the fall.

\section{Sin as unbelief: Luther's tale of original $\sin ^{20}$}

Luther argues that humans in their original state were in the image of God. However, this did not lie in any interior capacity, such as reason, or will, or intelligence, nor did it lie in a physical resemblance, such as the upright posture of human beings. No, "the image of God is something far different, namely, a unique work of God" (Luther 1958:62). Whatever our image is, it is such because God actively works and relates to it in a particular way. For Luther, God speaks reality into existence by the Word. This work of God is God's gift of grace and life, God's gift of an active relationship and discourse with creatures. Grace and life here are spoken, relational terms, designating the creature's relation to the God whose own essence is grace and life. In this state, human beings live a life that is very good and in line with God's will, free of fear of death and free of anxiety. Luther tells us that Adam and Eve lived a life full of love of God and of each other, completely for, and in recognition of, each other (Luther 1958:63). For Luther, God originally commanded that it should be this way: God prohibits eating from the tree of good and evil, and threatens death as punishment for disobedience. God gives God's own Word to establish a positive relationship with humanity. Human beings receive their existence by an act (a declaration) from outside themselves. Obedience to God in this sense simply means that humans acknowledge that this is the case. All humanity had to do, was peacefully co-exist with the rest of God's creatures, in a lush world of ample

19 An obvious question for Luther at this point is the following: who is he primarily speaking to? Are not the disproportionately wealthy and powerful the ones who have caused many of the problems we are facing? There is no doubt that this is the case. And Luther has a particular way of describing the selfishness of the rich and powerful, those whom McKibben identifies in his article as the ones most in need of change: the selfish have made an "idol of [their] belly" (Luther 1960, cf especially pp. 90-98). In this sense, the interjection of Luther is directed at those who are disproportionately powerful. Luther in his own day shows no patience with those who accumulate wealth and power and thus oppress the poor, as we see in the relentless criticism of them in his, A treatise on good works (1520) and, On trading and usury (1524). The powerful are most in need of a change of consciousness because they are most profoundly wrapped up in their own selfishness. But it is equally necessary for all to take note of Luther's entrance into this discussion of the ecological crisis, since even the least of these, once they see the liberation of justification and justice, are the ones who in solidarity know and speak this truth incessantly in order to effect change.

20 I rely heavily on the work of Piotr J. Malysz (2018) on Genesis, sin, and the law for the account I offer in the next few paragraphs. For a complete version of his argument, beyond the topic under consideration here, see pp. $15-44$. 
resources for the flourishing of all living things. This is none other than the First Commandment: I am the Lord thy God. God is God, creatures are creatures. God's command is God's speech to human beings: it is God's Word, and all this Word asks is that humans acknowledge that God is God and they are creatures. They possess complete freedom, freedom for God and for each other. By living in the light of this truth, they let God be God.

The great temptation from Satan is, then, one which presses humanity to listen to another word rather than God's own. As soon as we begin to take another word that claims to tell the truth about ourselves, God, and the world seriously, we sin. Original sin for Luther is unbelief: "Unbelief is the source of all sins; when Satan brought about this unbelief by driving out or corrupting the Word, the rest was easy for him" (Luther 1958:147). If human beings originally lived in a state wholly oriented toward the trustworthy Word of God, and thus as creatures of faith, then to sin is to lose this faith and to begin to lack trust in God's Word, the Gospel. What was originally "Gospel and Law" (Luther 1958:146), ${ }^{21}$ because God's Word to humanity at that point was one which set the foundation for a proper divine-human relationship - one simply built around humanity's free and loving openness to, and recognition of, God and neighbour becomes a law which now condemns. This condemnatory law is the law Luther elucidates so clearly in the disputations above. Humans now become uncertain of whose word to trust: God's, or someone else's? Due to a lack of faith in God's original Word, humans listen to other words and invent false gods. Precisely because idols are false (since there is only one God), they exist "nowhere"(Luther 1958:148). Luther states succinctly: "The source of all sin is unbelief and doubt and abandonment of the Word. Because the world is now full of these, it remains in idolatry, denies the truth of God, and invents a new god" (Luther 1958:149). Trusting in a word other than God's, is simply idolatry, since God is the Word God speaks.

What causes this invention of new gods? Our unbelief, doubt, fear, and despair. As soon as the original Word of God is no longer trusted, the voice of the serpent demands an audience. "Behind the good will of God", then, "there now looms another will, not good, but uncertain and untrustworthy" (Malysz 2018:18). It is a short step from here to complete lack of trust in any word, and thus from this point to a total reliance on our own being as we run in fear from the Word of God. Adam and Eve fear punishment for their disobedience, which they clearly display by hiding. God has not yet spoken to them after their eating of the fruit, yet trust is lacking. Therefore, when God calls after Adam and Eve, "Where are you?", all they heard were "words of the Law" (Luther 1958:173). Recall as noted above that the purpose of the law is to reveal sin. Piotr Malysz captures the pertinent issue: "God's whole being - in its inscrutability and unreliability - is now a threat" (Malysz 2018:19). Instead of a loving and gracious God, Adam and Eve conceive God to be inherently untrustworthy, a threat, and oppressive. This is the case because their conscience and orientation to God has been completely disrupted, and it quickly spirals out of control. As a consequence of their lack of belief, humans cannot help but fear and hate God, for the beckoning "where are you?" only oppresses the conscience. As a result of $\sin$, Luther tells us that now "we have no knowledge about what God is, what grace is, what righteousness is, and finally what sin itself is" (Luther

21 "In that order!" as Malysz well recognises (2018:18). 
1958:141). At this point, then, our entire reality becomes ambiguous. We do not know whom to trust. Thus, we invent gods and idols. We falsely project notions of the good. This is nothing other than to begin to justify ourselves. We only have ourselves and the world around us to go by, and so we become as "hypocrite[s] ... the material and the worker at the same time", which is nothing other than "creature and creator at the same time" (Luther 1963:259). This is a contradiction of our essence as created, for we go about a process of constructing our own existence out of the materials at hand. Malysz helpfully notes that "one is thus constantly delivered up to oneself, inexorably faced with being less than one desires to be, or feels one ought to be" (2018:21). Alternatively, due to the overwhelming threat of law that lies heavy on our conscience, we despair (which is equally sin because it too expresses fundamental unbelief). How could we do any better than that? According to Luther, we cannot, because we have no word of guarantee that what we are doing, is good, loving, or just. This is the height of sin. In our creation of idols and false projections, all we are really doing, is casting images of our own desires and false hopes; our failed hopes, since we never live up to the creations and projections of ourselves that we repetitiously enact, often lead us to despair. Again, the law - whether God's or our own - always accuses. We live in a muddle.

Outside of Luther's explicit, biblically focused analysis, a quick reflection on our own situation as finite and fragile subjects in an ever evolving, infinite cosmos, reveals the same situation. As Wolfhart Pannenberg (1994) grasps well, in order to cope with the magnitude of the cosmos, which he argues is our constant presence before the "infinite", and more specifically, the various crises we face in this infinite cosmos, we often lift up our own, finite selves as the centre of reference for any understanding, and management of, the rest of reality. ${ }^{22}$ Whether individually or collectively, people, peoples, and nations often anxiously protect themselves against the future, or against each other, with their own selves as the grounding, reference point. Following Søren Kierkegaard, Pannenberg dubs this simply the "anxiety of the self about itself" (1994:261). We build a world of concepts and institutions intent on protecting ourselves against whatever might be perceived as a threat, whether such a threat is explicit and conscious - a perceived enemy at our border - or unconscious - that feeling of dread and despair in facing the uncertain future. With our own self as reference point, the fact that we can even make a choice of action as something other than a "commitment to the good" already demonstrates our fragility and weakness as human beings. Pannenberg thus simply defines "sin as our human weakness relative to our destiny" (1994:258-259). We are always already entangled in evil and wrongdoing. ${ }^{23}$

For Luther, without grace, everything is menacing law, because we lost our original trust in the Word of God. All words of God without the clear promise of the Gospel are law, and these words constantly threaten. Malysz helpfully clarifies this: in "fact ... the unbeliever [the one who no longer has possession of God's trustworthy word, the one

22 See Pannenberg (1994), especially pp. 231-265.

23 To the objection that evil choices result from a neutral, free will, which thus might provide merely a secular, neutral concept/ground and thus absolve us from considering the theological concept of "sin" as a better way of thinking through evil in this world, Pannenberg reinforces the point that we are never neutral, and always caught up in systems of wickedness: "Hence it will not suffice to appeal to an act of free choice in explanation of the origin of evil and responsibility for it. If we do this, responsibility for a disposition that comes to expression in acts is confused with responsibility for an individual act" (1994: 259). 
who lacks faith] ... enacts the formal law of his or her collapsed self, the law that now drives the unbeliever to the contradictory self-expression as both a would-be god and an unfinished creature" (Malysz 2018:22). This means, Luther tells us, that humanity is "so turned in on [itself] that [it] uses not only physical but even spiritual goods for [its] own purposes and in all things seek only [itself]" (Luther 1972:345). In other words, we are selfish beings. Because we have lost trust in the original, clear Word of God, we are stuck with ourselves as an unending project. ${ }^{24}$ This project concerning ourselves leads us to continually fail to make something of ourselves, or, alternatively, causes us to despair over our ever-mounting failed attempts.

\section{Luther, the critics, and hints of a way forward Luther and the critics of Western Christianity}

Luther's tale about the origins of human sin explains why he says what he does in the two disputations examined above. When we no longer have a clear Word of God to guide us, to trust, to believe in; we make up our own, and a spiraling process ensues in which we become worse. We keep creating new gods, step up reliance on ourselves, and make use of whatever we can get our hands on in the process to aid our self-justification and protect ourselves against uncertainty. If this task becomes too daunting, and or if the law weighs heavily on us, we just keep on pressing forward, unaware of the gravity of the situation (as Luther says: we no longer know what sin is!), or we fear and despair. We simply attempt to move in an upward, self-transcendent direction. All these consequences demonstrate that we no longer trust God's Word. How could we? In this position, the most sensible thing to do, is to try the best we can to make something of ourselves, and hopefully improve ourselves in the process. As Luther says, however, we cannot become good, just, or righteous, and learn to love our neighbour, the earth, or God, simply by habituating good, just, or righteousness in ourselves. We have a law that we cannot ever live up to, one which always condemns and reveals our ineptitude. Thus, in order to begin to act in a goodly manner, something, or better, someone from outside of ourselves must interrupt our incurvatus in se. Before God, we are purely passive creatures. The process of being made righteous is a creative act of the Spirit of God in us, through a new clear Word that tells us who and what we are, and therefore frees us to be completely for our neighbour, the earth, and God. Luther distinguishes between the two gifts of mercy (grace) and righteousness. God's favour, on the one hand, is God's self-declared merciful relation to us; grace is God's Word of justification pronounced over us, freeing us from our own act of self-justifying. On the other hand, we remain material, sinful, fleshy creatures, and so God's gift of righteousness through the Holy Spirit moves us in this life, killing the old self and raising us anew in freedom before God and neighbour. We are promised future fulfillment through the Word and action of God in Christ, and now in this life the Spirit begins the process of healing. ${ }^{25}$ Instead of moving upward toward transcendence, God moves downward to us, becoming incarnate in the midst of the world, on a cross, no less! This is the picture we must grasp in order

24 Capitalism's penchant for continuous, even infinite, growth, and seemingly willful ignorance of our planet's finite resources, is one of our world's contemporary iterations of Luther's point. We have so elevated ourselves to positions of creative control over the earth's material resources that the fact that we are indeed also material, is ignored. We thus are very much creator and creature at the same time. 
to have the Zeitgeist changed. We shall see below how this works in Luther's theology of creation.

The ecologically conscious theologians who are critics of Christianity would obviously agree with Luther: humanity is the problem. Homo faber - man the maker and user of available tools and material - with a distorted consciousness, only produces injustice and evil, on display in full clarity in the exploits of colonialism, capitalism, and the ecological crisis. For Luther, as we will see below, this is not merely an interior issue for humans in their individual relationship to God. Instead, the issue also involves our entire field of external relations. God is only available mediated materially in creation, and the disrupted God-human relation affects all the relations in our environment (our ecology!). Luther and the critics examined above all identify human projection and selfcreation, especially as these undergird both our own status as humans and our crudely anthropomorphic projections of deity, as the problem. Thus, ecologically conscious critics would seem to agree with Luther in critiquing man the maker. But it is this precise point that is the issue to which Luther critically interjects and objects.

While the new visions for theology proffered in part one above might reject the personal God of Luther as unbelievable, outdated, or simply part of the problem, Luther counters and asks: who can tell all of us that what we do to each other and the earth is good or evil, is for the benefit of our neighbour or self-centred? The ecologically conscious theologians critique humanity the self-creator but seem to offer little more constructively than a diversified, conceptually ambitious, self-creator. Though our understanding of the human being is up to date - as evolved, on the plane of immanence, co-equal with all life-forms, fragile and not in any way special, subject to the becoming of the cosmos - the materials remain the same: ourselves and our environment. We work with what we have, to the best of our scientifically informed knowledge and based on our own rational judgments of who and what God (or we) could be. Ecologically conscious critics rightly name the sins of classical Western Christian conceptuality; they are serious, and they are many! But the problem is, such critiques displace the God whose favour leads us out of our sinful state. These critiques are left in dependence on their own word(s) alone. When everything is interconnected, we lack an account of why we are this way, and we remain mysteries to ourselves. Without the specific Word of grace and divine favour, how are we to judge a world of process and becoming? Put differently, do we ever have a guarantee that our actions will be just? God's law, or, put in secular terms, our self-consciousness and self-judgments, always accuse. Primavesi's call for justice demonstrates the problem acutely: we will know that our acts are just when we judge them ourselves in the future by our own standards of non-violence vis-à-vis the fragile creation. ${ }^{26}$ Whether we can say that our actions are non-violent toward our co-

See Primavesi (2000) pp. 72-80 on judgment and justice, and how these relate to God, pp. 137-153. One comment of hers is particularly telling: "If we hand over responsibility for the effects of our actions to God, then we hand over accountability for the quality of our present relationships and their future effects, on the (sometimes voiced) assumption that God will intervene (or not, as in the case of the Irish famine) to prevent future generations suffering from them. Our freedom disappears in direct proportion to the totalizing of divine omnipotence" (p. 141). Notwithstanding her lack of consideration of the classical position of noncompetitiveness between God and creatures because power or freedom are not shared in a zero-sum game, with Luther we can identify the core problem. Her account of God's deity in classical Christianity demonstrates precisely the analysis Luther provides in Genesis: Primavesi can only assume that God is a disembodied rationality, a word of law and command - one that we either fear or ignore (of course, because of 
evolving environment, or whether future iterations of humanity tell us so, this remains nothing other than an act of self-justification. And in this way, we are always caught in a process of both self-accusation and relentless judgment of others. From Luther's perspective, we have lost the story of who and what we are, with no one outside ourselves to tell us. Simply put: we cannot change our self-consciousness alone, nor does the interrelatedness and openness of all reality take us any further here. We are capable of realising the problems in which we are trapped, but at the deepest level we lack the capacity or vision to change ourselves. Left to our own self-judgment, the latter only causes more uncertainty. McKibben's article is direct evidence of this. Change takes time, and old habits die hard, but Lynn White wrote his provocative article over fifty years ago, and as McKibben details so thoroughly, things are no different, regardless of how much better informed we are. We have no assurance, no Word of God in which to trust, and we simply beg ourselves to change. With Luther, then, we need God extra nos. This is (still) the dramatic vision needed to have our consciousness changed.

\section{Luther's Theology of Creation: A way forward}

In opposition to the definition of humanity as self-creator, self-actualiser, and selfjustifier, actively working with the materials at its disposal, Luther defines humanity as follows: "Paul in Romans 3 [:28], 'We hold that a man is justified by faith apart from works,' briefly sums up the definition of man, saying, 'Man is justified by faith.", (Luther 1960:139). Humans are by definition human as justified beings by faith and grace alone, i.e., passively, by the activity of God alone. "Therefore," Luther tells us, "man in this life is the simple material of God for the form of his future life ... Just as the whole creation which is now subject to vanity [Rom. 8:20] is for God the material for its future glorious form" (Luther 1960:139). Life consists solely of the material: "But as this life is, such is the definition and knowledge of man, that is, fragmentary, fleeting, and exceeding material" (Luther 1960:138). As White, Ruether, Primavesi, and Kaufmann insist: we encounter God in the material becoming of the cosmos or not at all. Luther agrees! God's presence to creation is necessarily mediated materially, but who we encounter in the material, makes all the difference.

Luther argues that God is present to creation in three ways. First, God is present circumscriptively in the life and history of Jesus of Nazareth; here "space and object correspond exactly" (Luther 1961:215). This means that God's presence in Jesus is simply the space-time object of humanity's experience of the historical person Jesus of Nazareth at the beginning of the $1^{\text {st }}$ century. God is present in a specific time, in a particular place, and in a particular person, an object among other objects. Second, God again is in a definite place, but this time "in an uncircumscribed manner" (Luther 1961:215). This means that God is present in space and time, but is not restricted to space and time in our natural way of observing and experiencing it, i.e., God is not a simple, empirical object among other objects. An example of this can be found in the church's

our sinful false projections, it was almost inevitable that she conceives of God in this way). In fact, we hate such a God. Either way, according to her we simply must move on with ourselves and create ever-new godconcepts that best fit evolutionary and Gaia science. We have demonstrated the problems Luther has with such a position. We should note, however, that many of her comments concerning the God of rationality and law of Western Christianity are actually shared by Luther. He thus wants to address the issue head on; if Luther's analyses are correct, Primavesi only accentuates the problem. 
practice of the Lord's Supper: God is present in the bread and wine, but is not limited to the latter's material space and extension. There is more there than meets the eye. We also see this in the resurrected body of Jesus of the Gospel narratives: he passes through doors, for example. He is present in material reality but not limited by it. Finally, God is present in a third way "repletively" (Luther 1961:216) and supernaturally: "God is simultaneously present in all places whole and entire, and fills all places, yet without being measured or circumscribed by any place, in terms of the space which it occupies" (Luther 1961:216). This third mode of presence is the most important for us here. In this third mode, God is fully and completely present as God in the material, and, recall that the material is precisely that passive material on which God works the future. However, what is crucial here, is that the God encountered and grasped in the material is none other than the clear Word of Jesus Christ. Luther is worth quoting at length:

Here you must take your stand and say that wherever Christ is according to his divinity, he is there as a natural, divine person and he is also naturally and personally there ... But if he is present naturally and personally wherever he is, then he must be man there, too, since he is not two separate persons but a single person. Wherever this person is, it is the single, indivisible person, and if you can say, 'Here is God,' then you must also say, 'Christ the man is present too.' ... And if you could show me one place where God is and not the man, the person is already divided and I could at once say truthfully, 'Here is God who is not man and has never become man.' But no God like that for me! ... No, comrade, wherever you place God for me, you must also place the humanity for me. (Luther 1961:218-219)

What Luther makes so clear is that when we encounter God in the material reality, we encounter none other than Jesus Christ, fully God yet fully present to, in, and mediated by the material. If this is not the case, then we would not be certain that it is indeed God whom we encounter. Immediately we see a reversal of the picture of the fall. Sin originates when we cease trusting and believing in the clear Word of God. In Jesus Christ, God's Word is proclaimed anew, and it is the speaking of this particular Word that makes us who and what we are as human beings. Jesus Christ, the God-man, fully human and material, is the Word which "makes justice abound" (Luther $L W 31: 14$ ) and mediates grace. This specific Word is the key to a proper understanding of material reality, God's presence to it, and where it is going. Note, however, that this presence of God to the material is dynamic and open; it is the presence of God that works the future of the material. God is always ahead of us in this process. ${ }^{27}$ As we continue to learn about the reality in which we live, its fragility, its evolution, its dynamism and openness, we also encounter God's promised presence and active working there. Material reality is indeed dynamic, but relative to God, it remains passive. God's creative goodness, justice,

27 Again, pace Primavesi's account. "The 'deposit of faith,"” she tells us, "is presumed sealed against time and its effects" (2000:143). Of course, on her account of God after the fall, this is all she can say. But Luther's God, who creatively and actively works faith, is no timeless God. Rather, God is the truly creative one, the most active, but as such is personal. Thus, Luther's God who gives us faith through the Word is not at all incompatible with evolution and process. God is more open and dynamic than our reality could ever be because God is present to it materially, yet, as such, is also its future. Cf. Luther again on this issue in his Lectures on Genesis, $L W$ 1:27. 
and love make relational and remarkably dynamic reality what it is and will be. We are embedded in the material as bodies, and we only live, move, and have our being within this immanent frame. Encountering God's Word here frees us to do good and to love ourselves, God, and our neighbour because we now know what it is to do so. We do not create ourselves, nor do we have to make something of ourselves. We do not need to relate ourselves to some transcendental hierarchy of being, or consider some part of ourselves as separate from material reality (dualism). Instead, we hear who we are through the Word, and this frees us to be unconcerned with self-justification and thus free for our neighbour and the earth. The counterintuitive framework of a passivity upon which God actively operates by the Word alone, is the dramatic event that we must grasp in order to understand who we are. This is necessary due to the seriousness of sin. Perhaps the best way to understand the concept of "passivity" here, is in the following sense: when everything is so deeply interconnected, God's interruptive Word separates ourselves from ourselves, thus gifting us a freedom of conscience to evaluate who and what we are, what we are properly capable of (our limits), and what we should desire for the ecological future of this planet. Again, as noted above, it is not that God does our active works for us. We remain, as finite creatures, fully active. We do need, however, a Word, a promise, which, when spoken to us, does indeed tell us something new about who and what we are. Not only does this Word tell us how God favourably sees us, but it also arrives deep in the midst of material reality, witnessing to the creative, transcendent God's hidden presence in the human being Jesus of Nazareth.

When we turn to Luther's lectures on the early chapters of Genesis, we see God's radical presence to all creation in this third mode. Luther notes that God only makes Godself known by the Word (Luther $L W 1: 11$ ), and, as we saw above in the disputations, God's Word is the most active thing, that "operative Spirit" (Luther LW 31:13) which works the future flourishing of the material. It is, Luther tells us in his reflection on the Spirit hovering over waters at creation, "the office of the Holy Spirit to make alive" (Luther $L W$ 1:9). Regarding the visible and the material, i.e. the ecological environment in which we live and move, we need not imagine God to be anywhere else than where the Word promises to be! God is not the God that is much maligned by the critics of classical Christianity. No! God is deep in the flesh, radically present to material reality in all its fragility, its dynamism, and its immanence. "It is therefore insane," Luther states, "to argue about God and the divine nature without the Word or any covering" (Luther $L W 1: 13$ ). God is present there explicitly as material, i.e., as Christ Jesus, or God is not worth talking about. And Christ Jesus is nothing other than that Word of love, righteousness, and kindness that tells us we are loved, worthy, and gives us a future, in spite of our fragility and continual rejection of such a promise. We thus should never project false notions of transcendence, unlike "those who want to reach God apart from these coverings [who] exert themselves to ascend to heaven without ladders (that is, without the Word)" (Luther LW 1:14). Again, no! God creates all through the Word, and all material reality is expressive of this Word (Luther $L W$ 1:47). We need not look elsewhere. God's Word is even "present in the very body of the hen and in all living creatures" (Luther $L W 1: 53) .{ }^{28}$ For Luther all of this creation is materially bounteous and

28 We should note here that all of non-human creation is also given a future, and thus we do not justify it, nor does it justify us. The harm we inflict on nature certainly reveals that we continue to remain in bondage to our 
open, reflecting the providence of God that actively works the future of every organism, down to the minutest of details (Luther $L W$ 1:39ff.; 47ff.).

To the objection that Luther's God is radically anthropomorphic, he simply notes that such a judgment is incorrect. God reveals Godself in a radically simple way: in, by, and through the Word. As we saw above, we reject it at our own peril. This was God's original revelation by Word in the garden through the simplest of commands, and this is God's revelation in the clearest Word: "Behold, I am making all things new" (Rev. 21:5) continuously, in the material. Thus, when God reveals Godself in this way, "we [must] embrace this wrapper [the material], adoring, praying, and sacrificing to God there" (Luther $L W 1: 15$ ). Luther concludes this thought: whoever does not grasp this does not apprehend God, and does not let God be God in the way God wants to be (Luther $L W$ 1:15). And God wants to be God for us. Again, this mode of presence is God's hiding under the opposite. God is always active and working in creation, and this is God's hidden presence. In this sense, postcolonial and Lutheran theologian Vítor Westhelle rightly notes that God's radical presence to and in material reality is equally there in creation's beauty, yes, but also in all its entropy, fragility, and death (Westhelle 2017). Attention to this point in Luther is usually given to his early theology of the cross, where God lies hidden under the opposite (Luther $L W$ 31:52-53). ${ }^{29}$ For Luther, God is fundamentally creator and preserver of all that is. Though material reality comes into being and passes away (entropy, fragility, death), God is not finished with creation. God still actively creates: "Thus God creates throughout the entire world every day, even though he could have made [everything] at once" (Althaus 1966:106). As Paul Althaus notes, "God is not yet finished creating but is still working at it ... God is actively present, working and creating in all reality" (Althaus 1966:106; emphasis mine). God is present, period. Moreover, ${ }^{30}$ God is present and hidden even in our sin. To reject God's Word to humanity as crudely anthropomorphic, or to suggest that we should no longer concern ourselves with justification (salvation) but instead merely with justice, because God as personal saviour is simply inconceivable in the light of science, is to miss Luther's radical intervention in the discourse concerning the ecological crisis. In fact, Luther would add, this is the only way to have our consciousness changed so that we then are free to be for the world. We need someone outside of ourselves, but equally materially mediated, to free us from our incurvatus in se. We need separation from ourselves. Thus, "God's creativity is manifest in and through [our sin]. It is this creativity ... that makes knowledge of God possible" (Westhelle 2017:128). Recalling Luther's denunciation of false projections of transcendence, we do not see the visible workings of the cosmos and

sin, but it does not follow that the becomings of the cosmos and the material order, or a better knowledge of them, frees us to make changes in ourselves. The evolution of the created order, and the repetition of difference as time proceeds, merely enacts a repetitive ontic order. Thus, the deep structure of reality, that God relates to all that is not God via the Word, and the categories of grace and sin, are not worked out other than at this ontological and theological level. We must understand that God only works through the becoming of the created order, but we must see that God indeed works there in a specific way, in the Word of promise. In a recent, fascinating study, Steven Paulson (2019) traces this theme in Luther's theology with remarkable clarity. Paulson argues that the early ambiguities arising from the theology of the cross, and potential cross mysticism therein, get worked out as Luther more and more identifies God's presence in creation in the finite, all-too-human preacher of the Word. The logic behind the theology of the cross and God's hiddenness under the opposite does not disappear in Luther's thought, but instead becomes all the more radical.

30 It is necessary to note that ecologically conscious theologians too affirm that God is necessarily present immanently in the tragedy and fragility of the cosmos' becoming. Luther is not unique here. 
move to the invisible where God might be. No, God is not beyond. God deep in the material sends us "back to the depths of our own existence ... [where] the infinite is never attainable, but always present in the mirroring transparency of the visible" (Westhelle 2017:130). What is deeply visible is our sin and incapacity to effect real change, but it is precisely here that God's Word actively penetrates and frees us. God unwinds our incurved nature.

We clearly need a change of consciousness. The ecological crisis reveals to us that we are radically part and parcel of the material world within which we live, move, and have our being, and there is no outside. There is, however, a beyond the given. For Luther, we know this in the Word of grace, in the future opening Word that frees us from ourselves and for the neighbour and the earth. We either begin to seriously attend to the problems in our treatment of the environment, or we perish, as McKibben demonstrates. Hence the future of theology lies in thoroughgoing attention to the doctrine of creation and the production of creation theologies in order to address the great crisis of our time. Theology which does not address such serious problems, is a theology not worth doing. Those theologians who have worked on the ecological crisis over the last half century embody this attitude and practice, hence their rightful rejection of so much previous theology. Theologies need the proper resources for their tasks. The argument here has been: in the midst of this effort, why not examine Luther's theology of creation? As I have argued, Luther adds to a creation theology that necessary element for our consciousness to undergo change. In the midst of materiality, God interrupts the incurved spiral of sin wound so tightly in and around us, through a clear Word about creatures: grace, mercy, forgiveness, favour. This Word frees us to be a certain way toward each other and all creatures, and we do not have to keep justifying ourselves, unsure of what we are doing and where we are going.

\section{BIBLIOGRAPHY}

Althaus, Paul. 1966. The Theology of Martin Luther, trans. Robert C. Shultz. Philadelphia: Fortress Press.

Aristotle. Nicomachean Ethics, rev. ed. Jonathan Barnes and Anthony Kenny (2014). Princeton: Princeton University Press.

Forde, Gerhard O. 1990. Justification by faith: A matter of death and life. Eugene: Wipf \& Stock.

Jones, Serene. 2000. Feminist theory and Christian theology: Cartographies of grace. Minneapolis: Fortress Press.

Jüngel, Eberhard. 2014. Justification: The heart of the Christian faith. London: Bloomsbury.

Kant, Immanuel. 2000. Critique of the power of judgment, ed. Paul Guyer and trans. Paul Guyer and Eric Matthews. Cambridge: Cambridge University Press.

Kaufmann, Gordon. 2000. In the beginning... Creativity. Minneapolis: Fortress Press. .2004. Response to Elizabeth Johnson. In Dieter T. Hessel and Rosemary Radford Ruether (eds), Christianity and ecology: Seeking the well-being of earth and humans. Cambridge: Harvard University Press, 22-27. 
2006. Jesus and creativity. Minneapolis: Fortress Press.

Luther, Martin. 1957. Luther's works 31: The career of the Reformer I, ed. Harold J. Grimm. Philadelphia: Fortress Press.

. 1958. Lectures on Genesis 1-5, ed. Jaroslav Pelikan, trans. George V. Schick.

Luther's works vol. 1. Saint Louis: Concordia.

. 1958. Luther's works vol. 32: Career of the Reformer II, ed. George W. Forell.

Philadelphia: Muhlenberg Press.

. 1959. Luther's works vol. 36: Word and sacrament II, ed. Abdel Ross Wentz.

Philadelphia: Muhlenberg Press.

. 1960. Luther's works vol. 9: Lectures on Deuteronomy, ed. Jaroslav Pelikan.

Saint Louis: Concordia.

. 1960. Luther's Works vol. 34: Career of the Reformer IV, ed. Lewis W. Spitz.

Philadelphia: Muhlenberg Press.

1961. Luther's works vol. 37: Word and sacrament III, ed. and trans. Robert H.

Fischer. Philadelphia: Fortress Press.

. 1963. Luther's works vol. 26: Lectures on Galatians 1535 Chapters 1-4, ed.

Jaroslav Pelikan. Saint Louis: Concordia.

. 1972. Luther's works vol. 25: Lectures on Romans, ed. Hilton C. Oswald. Saint Louis: Concordia.

Malysz. Piotr J. 2018. The law in the Lutheran tradition. In Jonathan A. Linebaugh (ed.), God's two words: Law and Gospel in the Lutheran and Reformed Traditions. Grand Rapids: Eerdmans, 15-44.

McKibben, Bill. 2018. How extreme weather is shrinking the planet, The New Yorker, November 26, 2018.

Moe-Lobeda, Cynthia D. 2002. Healing a broken world: Globalization and God. Minneapolis: Fortress Press.

Pannenberg, Wolfhart. 1994. Systematic Theology vol. 2. Grand Rapids: Eerdmans.

Paulson, Steven D. 2019. Luther's outlaw God vol. 2: Hidden in the cross. Minneapolis: Fortress Press.

Primavesi, Anne. 2000. Sacred Gaia: Holistic theology and earth system science. New York: Routledge.

Reuther, Rosemary Radford. 1993. Ecofeminism: Symbolic and social connections of the oppression of women and the domination of nature. In Carol J. Adam (ed.), Ecofeminism and the sacred. New York: Continuum, 13-23.

Westhelle, Vítor. 2017. Transfiguring Luther: The planetary promise of Luther's theology. Cambridge: James Clark \& Co.

White, Lynn Jr. 1967. The historical roots of our ecological crisis, Science 155 (10 March 1967):1203-1207. 